Schilling, W. \& Schmatz, W. (1964). Phys. Stat. Sol. 4, 95-101.

Schmatz, W. (1973). In Treatise on Materials Science and Technology 2, Edited by H. Herman. pp. 105-229. New York: Academic Press.

Schmatz, W. \& Kaiser, B. (1966). Report of the Consultants Symposium The Nature of Small Defect Clusters, 1, pp. 268-280. AERE-R 5269.

Schmatz, W. \& Schelten, J. (1971). J. Appl. Cryst. 4, 410.

Schmatz, W., Berndorfer, K. \& Durcansky, G. (1971). Suppl. J. Phys. Radium, 11. C1, 679-680.

SchöNAUER, L. (1968). Diploma work, Technische Univ. München.

Seeger, A. \& Brand, P. (1965). In Small Angle X-Ray Scattering. Edited by H. BRUMBerger, pp. 383-399. New York: Gordon \& Breach.

SeEger, A. \& Kröner, E. (1959). Z. Naturforsch. A 14, 74 80.

Seeger, A. \& Kronmüller, H. (1959). Phys. Chem. Solids. 12, 298-313.

Segger, A. \& Rühle, M. (1963). Ann. Phys. 2, 216-229.
SHull, C. G. (1972). Table of Coherent Neutron Scattering Amplitudes (compiled February 1972, Department of Physics, Massachusetts Institute of Technology).

Springer, T. \& Schmatz, W. (1967). Bull. Soc. Fr. Minér. Crist. 90, 428-435.

Stork, A. (1967). Z. Phy's. 198, 386-408.

Stork, A., Christ, J. \& Schmatz, W. (1965). Z. angew. Phys. 18, 468-471.

Stuhrmann, H. B. (1974). J. Appl. Cryst. 7, 173-178.

Taglauer, E. (1968). Phy's. Stat. Sol. 29, 259-268.

Thomas, J. E., Baldwin, T. O. \& Dederichs, P. H. (1971). Phys. Rev. B3, 1167-1173.

Thorel, P., Kahn, R., Simon, Y. \& Cribier, D. (1973). J. Phys. Radium, 34, 447-452.

Trenzinger, K. (1966). Diploma work, Technische Hochschule München.

Turchin, V. F. (1965). Slow Neutrons, Israel Prog. Scientific Translations.

Weber, H. W., Schelten, J. \& Lippmann, G. (1973). Phy's. Stat. Sol. (b), 57, 515-522.

Wignall, G. D., Schelten, J. \& Ballard, D. G. H. (1974). J. Appl. Cryst. 7, 190.

J. Appl. Cryst. (1974). 7, 116

\title{
Applications of Position-Sensitive Proportional Counters to Neutron and X-ray Scattering Experiments*
}

\author{
BY C. J. BORKOWSKI AND M. K. KOPP \\ Oak Ridge National Laboratory, Oak Ridge, Tennessee 37830, U.S.A.
}

\begin{abstract}
The authors review the characteristics of position-sensitive proportional counters (PSPC) with RC line signal encoder [Borkowski, C. J. \& Kopp, M. K. (1968). Rev. Sci. Instrum. 39, 1515] and discuss some applications of one- and two-dimensional PSPC's to neutron and X-ray scattering experiments. Compared to other methods, the RC line signal encoding method features relative simplicity in construction and operation plus flexibility in design. Furthermore, these PSPC's show good spatial and energy resolutions, high data-acquisition rates, and good detection efficiency for low-energy $(<150 \mathrm{keV})$ gamma or $X$-rays and thermal neutrons. The spatial uncertainty with a $200 \mathrm{~mm}$ long, one-dimensional PSPC is $0.15 \mathrm{~mm}$ (fwhm) for $6 \mathrm{keV} \mathrm{X}$-rays or $5 \mathrm{MeV} \alpha$ particles. For thermal neutrons, the spatial uncertainty is $0.4 \mathrm{~mm}(\mathrm{fwhm})$ with a $500 \mathrm{~mm}$ long, one-dimensional PSPC. A two-dimensional PSPC of $200 \times 200$ $\mathrm{mm}$ sensitive area has 40000 resolution elements of $1 \times 1 \mathrm{~mm}$ each. The energy resolution is $760 \mathrm{eV}$ (fwhm) for $6 \mathrm{keV}$ X-rays. In recent work the authors have extended the data acquisition rate by reducing the signal processing time to $0.5 \mu \mathrm{s} /$ event while maintaining excellent spatial resolution.
\end{abstract}

\footnotetext{
* Research sponsored by the U.S. Atomic Energy Commission under contract with the Union Carbide Corporation.
} 